\title{
Pengembangan Instrumen Penilaian Diri (Self Assesment) Untuk Menilai Karakter Spritual Pada Pembelajaran Sosiologi Kelas XI SMA
}

\author{
Aulia Putri Wandia ${ }^{1}$, Ike Sylvia ${ }^{2}$ \\ ${ }^{1,2}$ Universitas Negeri Padang \\ Email: auliaputriwandia1999@gmail.com, ikesylvia@fis.unp.ac.id
}

\begin{abstract}
Abstrak
Penelitian ini merupakan penelitian dengan jenis research and development, yang bertuajuan untuk mengembangkan instrumen penilaian diri untuk mengukur sikap religius peserta didik pada pembelajaran sosiologi SMA. Model pengembangan yang digunakan adalah $4 \mathrm{D}$ yaitu: tahap pendefinisian (Define), tahap perencanaan (Design), tahap pengembangan (Develop), dan tahap Diseminasi (Disseminate). Teknik pengumpulan data pada penelitian ini menggunakan instrumen pelaksanaan pembelajaran, instrumen validasi ahli, angket praktikalitas dan soal untuk menguji efektifitas. Teknik analisis data menggunakan analisis $\mathrm{r}$ product moment untuk menganalisa hasil validasi ahli, persentase untuk mengukur praktikalitas, dan uji $t$ untuk mengukur efektifitas. Penelitian ini diujicobakan pada pembelajaran sosiologi kelas XI IPS 1 SMAN 1 Linggosari Baganti Pesisir Selatan, memperoleh hasil validitas produk (instrument penilaian diri, RPP dan Soal) dalam kategori sangat tinggi, hasil pretest dan posttest menunjukkan bahwa produk penelitian ini efektif. Dengan demikian dapat disimpulkan instrumen penilaian diri yang dihasilkan dapat mengukur ranah afektif peserta didik khususnya sikap spiritual.
\end{abstract}

Kata kunci: Instrumen Penilaian, Pengembangan, Sikap Spiritual, Sosiologi

\section{Abstract}

This research is a research and development type, which aims to develop a self-assessment instrument to measure the religious attitudes of students in high school sociology learning. The development model used is $4 D$, namely: the defining stage (Define), the planning stage (Design), the development stage (Develop), and the Dissemination stage (Disseminate). Data collection techniques in this study used learning implementation instruments, expert validation instruments, practicality questionnaires and questions to test effectiveness. The data analysis technique uses $r$ product moment analysis to analyze the results of expert validation, the percentage to measure practicality, and the t test to measure effectiveness. This research was tested on sociology learning class XI IPS 1 SMAN 1 Linggosari Baganti Pesisir Selatan, obtained the results of product validity (self-assessment instruments, lesson plans and questions) in very high categories, the results of the pretest and posttest showed that the research product was effective. This it can be concluded that the resulting self-assessment instrument can measure the affective domain of students, especially spiritual attitudes.

Keyword: Development, Instruments of Assessment, Sociology, Spiritual Attitudes

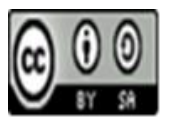

Received: May 2, $2021 \quad$ Revised: May 27, 2021 $\quad$ Accepted: May 28, 2021 


\section{Pendahuluan}

Sistem pendidikan nasional yang tercantum dalam UU no 20 tahun 2003 menyatakan bahwa pemerintah memastikan pelaksanaan pendidikan yang berkualitas bagi setiap warga negara, oleh karena itu diperlukan pengerahan tenaga yang maksimal dalam meningkatkan kualitas pendidikan. Dengan pernyataan ini, upaya untuk meningkatkan pendidikan tidak akan tercapai tanpa ada peningkatan pada kualitas pembelajaran.

Peningkatan kualitas pembelajaran mengharapkan adanya upaya untuk memajukan proses dan hasil belajar. Upaya untuk meningkatkan hasil pembelajaran tidak akan pernah terlepas dari pelaksanaan proses pembelajaran yang berkualitas pula. Artinya pelaksanaan proses pembelajaran perlu dirancang terlebih dahulu dan konsisten dengan evaluasi pembelajaran yang dilaksanakan, agar mencapai kompetensi yang diharapkan.

Mata pembelajaran sosiologi adalah salah satu mata pembelajaran yang wajib dipelajari pada jenjang SMA. Dalam Permendiknud no 59 tahun 2014 kurikulum 2013 bahwa tujuan dari pembelajaran sosiologi adalah (1) meningkatkan penguasaan pengetahuan sosiologi dikalangan yang berorientasi pada pemecahan masalah dan pemberdayaan sosial, (2) mengembangkan pengetahuan Sosiologi dan melaksanakan aplikasi dari pengetahuan tersebut untuk meningkatkan keterampilan sosial dalam memecahkan masalah-masalah social, (3) enumbuhkan sikap religius dan etika sosial yang tinggi di kalangan sehingga memiliki kepekaan, kepedulian dan tanggungjawab memecahkan masalah-masalah sosial. Dari tujuan pembelajaran sosiologi pada kurikulum 2013 ini dapat disimpulkan bahwa didalam proses pembelajaran sosiologi tidak hanya terfokus dalam meningkatkan kemampuan pada aspek kognitif, tetapi juga meningkatkan kemampuan sosial dan religius. Dan keterampilan, sehingga pembelajaran tidak boleh fokus untuk meguasai materi secara teori saja tapi juga dituntut lebih peka terhadap gejala sosial yang di masyarakat.

Penilaian merupakan bagian yang penting dalam pembelajaran. Menurut Mucthar Hartati (Hartati, 2010) penilaian merupakan bagian integral dari proses pembelajaran. Sedangkan Menurut Ridwan Abdullah Sani penilaian adalah upaya yang disengaja dan mendasar yang dibawa melalui pengumpulan informasi atau data yang sah dan dapat diandalkan, dan kemudian informasi atau data tersebut disiapkan sebagai karya untuk membuat perenungan untuk pembuatan strategi dalam program instruktif. (Sani, 2016). Penilaian adalah suatu proses berkelanjutan tentang pengumpulan dan penafsiran informasi untuk menilai keputusankeputusan yang dibuat dalam merancang suatu sistem pengajaran (Lutasari, 2018).

Penilaian dalam pembelajaran sosiologi perlu memperhatikan karakteristik ilmu sosiologi dalam proses pelaksanaannya. Misalnya dengan mengintegrasikan pembelajaran dengan melihat sebuah fenomena dalam kehidupan bermasyarakat, dan mengkonstruksi konseptualisasi fenomena tersebut ke dalam sebuah konsep dan teori yang sesuai. Oleh karena itu penilaian tidak dapat terlepas dari proses pembelajaran, dan pelaksanaan proses penilaian dalam pembelajaran yang tepat dapat menunjukkan kemampuan guru sebagai pendidik professional. Oleh karena itu pelaksanaan penilaian yang sesuai dengan kompetensi yang diharapkan akan membawa dampak pada keberhasilan suatu pendidikan.

Penilaian memiliki tujuan, meliputi (1) menilai kemampuan individual melalui tugas tertentu, (2) menentukan kebutuhan pembelajaran, membantu dan mendorong , (3) membantu dan mendorong guru untuk mengajar yang lebih baik, (4) menentukan strategi pembelajaran, (5) akuntabilitas lembaga, dan (6) meningkatakan kualitas pendidik. Berdasarkan tujuan penilaian ini, maka proses penilaian yang seharusnya dilakukan oleh seorang guru hendaknya mampu melihat kemajuan yang diperoleh dari dalam proses pembelajaran. Oleh karena itu untuk melakukan penilaian kepada tidak hanya melihat dari akhir hasil belajar namun dimulai dari perencanaan yang jelas dan dilaksanakan pada proses pembelajaran. Dengan melakukan penilaian, pendidik sebagai pengelola kegiatan, dapat mengetahui kemampuan yang dimiliki , ketepatan metode pembelajaran yang digunakan, dan keberhasilan dalam meraih kompetensi

Jurnal Sikola: Jurnal Kajian Pendidikan dan Pembelajaran Vol. 2, No. 4, Th. 2021 
yang telah ditetapkan (Alif, Nonoh, \& Sarwanto, 2015). Selain itu seorang guru harus memperhatikan tiga ranah dalam sebuah penilaian yaitu kognitif, afektif dan psikomotorik. Sesuai yang disampaikan oleh Darmadji (Darmadji, 2011) bahwa ketiga ranah tersebut merupakan karakteristik dalam proses pendidikan. Untuk itu pendidik harus memiliki instrumen yang berkualitas, yaitu instrumen yang memiliki jangkauan dan legitimasi, sehingga dapat memberikan data yang tepat. Seperti yang diungkapkan oleh Tuckman, perangkat tes atau instrumen tes harus dipertanggung jawabkan (Nurgiyantoro, 2010).

Selama ini, penilaian yang dilakukan oleh guru hanya terbatas mengukur kemampuan pada aspek kognitif, sedangkan untuk mengukur psikomotor, guru melihat dari hasil kinerja yang telah dikerjakan oleh. Guru masih jarang menggunakan instrumen penilaian dalam mengukur kemampuan terutama pada aspek afektif. Hal tersebut berbanding terbalik dengan apa yang tercantum dalam ketetapan yang harus dilaksanakan dalam proses pembelajaran menurut Kurikulum 2013 sebagai implementasi dari standar nasional pendidikan yaitu penilaian afektif menjadi satu komponen yang sangat penting yang harus dilakukan oleh guru. (Menteri Pendidikan Dan Kebudayaan RI, 2013). Afektif berhubungan dengan perasaan seperti sentimen, nilai, penghargaan, inspirasi dan perspektif. Penilaian afektif juga disampaikan oleh (Saftari \& Fajriah, 2019) diidentikkan dengan minat dan mentalitas seperti keaslian, kedisiplinan, keyakinan diri, dll.

Studi pendahuluan yang peneliti lakukan di SMAN 1 Linggo Sari Baganti, melalui proses wawancara, observasi dan dokumentasi penilaian, diperoleh data guru masih jarang melakukan penilaian pada aspek afektif, guru terfokus melaksanakan penilaian pada aspek kognitif dan psikomotorik. Hasil wawancara juga menyebutkan bahwa saat dilakukan penilaian kinerja (psikomotor) guru tidak dapat langsung melaksanakan penilaian afektif, karena guru tidak memiliki instrument yang sesuai dengan rancangan proses pembelajaranya. Selain itu pada saat melakukan penilaian kinerja melalui kemampuan dalam diskusi kelompok, hanya beberapa orang saja yang aktif menganggap bahwa proses pada saat diskusi tidak dinilai. Sehingga hasil belajar yang diperoleh tidak mampu memperlihatkan kompetensi pada ranah afektif.

Berdasarkan hasil studi pendahuluan yang dipaparkan di atas terlihat bahwa ketiadaan penilaian afektif dilaksanakan dalam proses pembelajaran adalah karena tidak adanya instrumen yang sesuai dengan rancangan proses pembelajaran guru. Sehingga dibutuhkan instrument penilaian afektif yang dapat digunakan, fleksibel terhadap kondisi pembelajaran, dan dapat digunakan dengan mudah, sehingga perkembangan kompetensi dapat dipantau. Oleh karena itu dibutuhkan suatu instrumen penilaian agar kegiatan pembelajaran berjalan dengan maksimal. Salah satu teknik penilaian yang bisa digunakan adalah penilaian dengan teknik self assesment atau penilaian diri. Menurut Arifin (R. Arifin, Kusumah, \& Mubarak, 2018) penilaian diri merupakan suatu metode untuk mensurvei perspektif, informasi dan kemampuan yang diselesaikan oleh pada umumnya. Sedangkan menurut Muawwan (Muawwan, 2018) penggunaan metode ini dapat mempengaruhi peningkatan karakter . Instrumen penilaian diri dapat membantu mengevaluasi rasa percaya dirinya, karena diberi kebebasan untuk menilai diri serta kekurangan dan kualitas mereka sendiri. Karena ketika mereka melakukan evaluasi mereka harus introspeksi kualitas dan kekurangan mereka, mendorong dan melatih mereka untuk bertugas karena mereka harus jujur dan objektif dalam membuat penilaian. Hal tersebut juga disampaikan dalam Panduan Penilaian Oleh Pendidikan Dan Satuan Pendikin untuk SMA bahwa penilaian diri oleh dibantu melalui kemajuan yang menyertai kemampuan : mengungkapkan alasan penilaian diri kepada, memutuskan petunjuk yang akan disurvei, memutuskan tindakan evaluasi yang akan digunakan dan merencanakan desain penilaian, sebagai pemeriksaan rutin atau skala penilaian atau sebagai eksposisi untuk mendorong untuk memahami diri mereka sendiri dan kepastian laten mereka. (Kemendikbud RI, 2017). Mulyasa juga menyatakan bahwa penilaian diri merupakan strategi penting dalam perubahan tingkah 
laku. (Mulyasa, 2003) Hal ini berarti bahwa pengembangan potensi manusia atau intelektualnya akan berbanding lurus dengan pengembangan kepribadiannya (self-actualization).

Instrumen penilaian diri memiliki kegunaan antara lain (1) mendorong keberanian pada , karena mereka diberikan kepastian untuk mensurvei diri mereka sendiri, (2) pemahaman tambahan tentang kualitas dan kekurangan mereka, (3) mempersiapkan dan menyesuaikan diri dengan secara terus terang (Himatus Sofiya, 2013). Keuntungan dari penggunaan penilaian selfassessment dan peer assessment di kelas antara lain dapat menumbuhkan rasa percaya diri , karena mereka diberi kepercayaan untuk mengevaluasi dan menilai dirinya sendiri, menyadari kelebihan dan kelemahan dirinya, karena ketika mereka melakukan penilaian harus melakukan introspeksi terhadap kelebihan dan kelemahan yang dimilikinya dan dapat mendorong, membiasakan, dan melatih untuk berbuat jujur, karena mereka dituntut untuk objektif dalam melakukan penilaian. (Wijayanti, 2017) Berkaitan dengan uraian dan fakta di atas, maka peneliti memandang perlu melakukan penelitian yang bertujuan untuk mengembangkan instrumen penilaian diri yang dapat digunakan pada pembelajaran sosiologi SMA dan memaparkan hasil penilaian diri setelah mereka melaksanakan proses pembelajaran yang melibatkan aktifitas yang dapat mengelaborasi kemampuan mereka. Pada artikel ini peneliti memaparkan hasil pengembangan instrumen penilaian diri yang telah dirancang dan digunakan oleh pada pembelajaran sosiologi SMA kelas XI IPS 1 di SMAN 1 Linggo Sari Baganti.

\section{Metode Penelitian}

\section{Model Pengembangan}

Metode yang digunakan pada penelitian ini adalah metode penelitian dan pengembangan atau lebih dikenal dengan Research and Development (R\&D). Research and Development $(\mathrm{R} \& \mathrm{D})$ atau penelitian pengembangan adalah suatu proses atau langkah-langkah untuk mengembangkan suatu produk baru atau menyempurnakan produk yang telah ada sehingga dapat dipertanggung jawabkan. (Endang Widi Winarni, 2018). Penelitian pengembangan ini mengggunakan model penelitian 4-D (Four D), yaitu: tahap pendefinisian (Define), tahap perencanaan (Design), tahap pengembangan (Develop), dan tahap Diseminasi (Disseminate). Pemilihan model ini didasari atas pertimbangan model ini mudah dipahami, selain itu juga model ini dikembangkan secara sistematis dan berpijak pada landasan teoritis desian pembelajaran yang dikembangkan. Prosedur pengembangan instrumen penilaian diri pada pembelajaran sosiologi kelas XI IPS pada semester Januari-Juni 2021ini sesuai dengan langkah 4-D (Four D) dapat dijelaskan melalui sebagai berikut.

\section{Define (Pendefinisian)}

Pada tahap ini dilakukan kegiatan untuk menetapkan dan mendefinisikan syarat-syarat pengembangan. Tahap ini sering kali dinamakan dengan tahap analisis kebutuhan. Tiap-tiap produk memiliki analisis yang berbeda-beda. Pada pengembangan instrumen penilaian diri dilakukan berbagai analisis yaitu: (1) analisis kurikulum, (2) analisis karakteristik , (3) analisis materi, (4) analisis tujuan pembelajaran.

\section{Tahap Design (Perancangan)}

Pada tahap perancangan memiliki tujuan untuk merancang instrumen penilaian diri pada mata pelajaran sosiologi, pada tahap ini ada empat kegiatan, yaitu: constructing criterion referenced test, media selection, format selection, dan initial design. Kegiatan yang dilakukan pada tahap tersebut, yaitu:

\section{a. Constructing Criterion Referenced Test (Membangun Tes Referensi Kriteria)}

Menyusun tes kriteria sebagai tindakan pertama untuk mengetahui kemampuan awal sebagai alat evaluasi sebelum dan setelah implementasi kegiatan. Pada penelitian ini peneliti 
mengembangkan kisi-kisi soal dan soal pretest serta posttest yang dapat digunakan untuk materi pembelajaran sosiologi KD 3.4 konflik sosial dan IPK 3.4.9 resolusi konflik.

\section{b. Media Selection (Pemilihan Media)}

Pada tahap ini yang peneliti lakukan adalah memilih media pembelajaran yang sesuai dengan materi dan karakteristik yang dapat mengakomodasi Langkah-langkah pembelajaran yang telah disusun sesuai dengan model yang digunakan yaoti discovery learning. Peneliti Menyusun Langkah pengembangan perangkat pembelajaran yang akan dirancang dan disusun yaitu RPP (rencana pelaksanaan pembelajaran), LKPD (lembar kerja), serta instrumen penilaian diri pada materi pembelajaran sosiologi KD 3.4 konflik sosial dan IPK 3.4 .9 resolusi konflik. Selain itu juga peneliti merancang instrumen pengambilan data yang akan digunakan antara lain yaitu, soal atau tes, lembar angket validasi RPP, lembar angket validasi Instrumen penilaian diri dan lembar praktikalitas.

\section{c. Format Selection (Pemilihan Format)}

Pada langkah ini peneliti melakukan pemilihan bentuk penyajian pembelajaran disesuaikan dengan perangkat pembelajaran dan media pembelajaran yang digunakan. Peneliti memilih tampilan format dari instrumen penilaian diri yang akan dikembangkan ialah instrumen penilaian diri untuk mengukur sikap spritual.

\section{d. Initial Design (Rancangan Awal)}

Pada tahap ini peneliti menyelesaikan tahapan draft awal instrument penilaian diri beserta perangkat pembelajaran lainnya serta instrumen validasi yang siap diberikan keada ahli untuk diuji validitasnya.

\section{Tahap Develop (Pengembangan)}

Pada tahap pengembangan dilakukan validasi instrument penilaian diri beserta perangkat pembelaran lainnya oleh pakar atau ahli yang memiliki kompetensi. Ahli akan memberikan penilaian dan saran yang digunakan untuk memperbaiki pruduk yang akan dikembangkan sebelum dilakukan uji coba lapangan. Tahapn ini menghasilkan skor peneilaian ahli dan masukan untuk revis produk.

\section{Tahap Dissaminate (Penyebaran)}

Tahap penyebaran merupakan tahap penggunaan produk yang telah divalidasi oleh ahli dan direvisi oleh peneliti menjadi produk akhir yang layak diujicobakan. Produk penelitian ini yaitu instrumen penilaian diri yang dapat digunakan pada saat pembelajaran materi KD 3.4 konflik sosial dan IPK 3.4.9 resolusi konflik. Pada tahap uji cob aini yang dilakukan adalah pengukuran efektifitas dan praktikalitas instrument penilaian diri beserta perangkat pembelajaran yang mendukung terlaksanaya proses pembelajaran pada materi tersebut.

\section{Subjek dan Objek Penelitian}

Uji coba instrumen dilakukan di SMA N 1 Linggo Sari Baganti. Adapun subjek uji coba dalam penelitian ini adalah seluruh yang ada di kelas XI IPS 1 yang berjumlah 35, yang mengisi instrumen penilaian diri yang telah dikembangkan, menguji keefektifan dan praktikalitas instrumen penilaian diri yang telah dikembangkan. Sedangkan objek penelitian adalah instrumen penilaian diri pada materi upaya penyelesaian konflik untuk membantu meningkatkan penilaian pada aspek sikap.

\section{Teknik Pengumpulan Data}

Teknik pengumpulan data dalam penelitian ini diperoleh melalui instrumen penelitian. Penelitian ini menggunakan instrumen yang berupa instrumen pembelajaran dan instrumen penelitian. 


\section{Instrumen Pembelajaran}

Adapun instrumen pembelajaran yang digunakan untuk mengumpulkan data yang menunjang pengembangan instrumen penilaian diri adalah (1) Rancangan Pelaksanaan Pembelajaran (RPP) untuk materi KD 3.4 konflik sosial dan IPK 3.4 .9 resolusi konflik yang mencakup pengembangan aspek kognitif, afektif dan psikomotor. Pada RPP ini digunakan model Discovery Laerning, (2) Lembar Kerja (LKPD).

\section{Instrumen Pengambilan Data}

1) Tes

Instrumen pengumpulan data pada penelitian ini adalah (1) Tes, dengan memberikan soal kepada pada kelas XI IPS 1 SMAN 1 Linggo Sari Baganti. Tes ini bertujuan untuk mengetahui pengetahuan awal (pretest) dan posttest. Setelah memberikan soal postest, guru akan memberikan lembar instrumen penilaian diri.

2) Angket Validasi Rencana Pelaksanaan Pembelajaran

Angket validasi Rencana Pelaksanaan Pembelajaran ini berguna untuk melihat valid atau tidaknya dari Rencana Pelaksanaan Pembelajaran yang dibuat. Validasi Rencana Pelaksanaan Pembelajaran ini dinilai oleh ahli yaitu: dua orang dosen sosiologi dan satu orang guru sosiologi. Saran dan komentar dari ahli tersebut akan dijadikan sebagai pedoman serta menentukan kelayakan dan validnya Rencana Pelaksanaan Pembelajaran. Berikut ini angket validasi RPP.

3) Angket Validasi Penilaian Instrumen Penilaian Diri

Angket digunakan untuk mengetahui kelayakan instrumen penilaian diri, serta digunakan untuk mengetahui perkembangan dari penelitian. Angket validasi ini direncang dan diberikan kepada tiga orang ahli yaitu dua orang dosen sosiologi dan satu orang guru sosiologi. Berikut ini angket validasi instrumen penilaian diri.

4) Angket Praktikalitas

Angket praktikalitas dibuat untuk mengukur praktikalitas instrumen penilaian diri yang dibuat, angket praktikalitas diberikan kepada 35 kelas XI IPS 1 SMAN 1 Linggo Sari Baganti dan satu orang guru sosiologi. Dari angket yang telah diisi oleh dan guru tadi akan dilihat apakah instrumen penilaian diri tersebut praktis digunakan untuk menilai sikap spritual.

5) Efektifitas

Efektifitas instrumen penilaian diri dilihat dari keyakinan dan kepercayaannya akan kemampuannya karena anugrah Tuhannya, maka tersebut dapat mengerjakan soal pretest dan postest dengan baik. Perbedaan nilai pretest dan postest dilihat melalui rumus t-test.

\section{Teknik Analisa Data}

\section{Analisis Data Uji Validitas}

Data skor hasil validasi ahli ditabulasi dan dianalisi menggunakan rumus $\mathrm{r}$ product moment, kemudian diinterpretasikan koefisien validasinya sesuai dengan kategori berikut:

Tabel 1. Pedoman Untuk Memberikan Interpretasi Koefisien Korelasi

\begin{tabular}{cll}
\hline No & Interval Koefisien & Interpretasi \\
\hline 1 & $0,00-0,19$ & Validasi rendah atau tidak valid \\
\hline 2 & $0,20-0,39$ & Validasi rendah \\
\hline 3 & $0,40-0,59$ & Validasi cukup \\
\hline 4 & $0,60-0,79$ & Validasi tinggi \\
\hline 5 & $0,80-1,00$ & Validasi sangat tinggi \\
\hline
\end{tabular}




\section{Analisis Data Uji Efektifitas}

Analisis data uji efektivitas diperoleh dari hasil belajar pada mata pelajaran sosiologi kelas XI IPS pada KD 3.4 materi konflik sosial dan IPK 3.4.9 resolusi konflik. Hasil belajar kelas XI IPS 3 ini dibandingkan sebelum (pretest) dan sesudah (posttest) dan dianalisis dengan program SPSS versi 26 rumus Analyze Paired-Sample T-Test. Uji hipotesis menggunakan program SPSS 16 Paired Sample T-Test pada nilai pretest-postest kelas eksperimen dan pretest - postest kelas kontrol dengan taraf signifikansi 5\%. Uji ini digunakan untuk mengetahui perbedaan antara ratarata nilai sebelum diberikan treatment (pre-test) dengan rata- rata nilai setelah diberikan treatment (pos-test). Sebelum dilakukan uji hipotesis terlebih dahulu dilakukan uji normalitas, homogenitas.

\section{Analisa Data Uji Praktikalitas}

Data uji praktikalitas instrumen penilaian afektif yang diperoleh dari pengguna, kemudian ditabulasi dan hasilnya diinterpretasikan sesuai dengan kategori berikut :

Tabel 2. Kategori Praktikalitas

\begin{tabular}{rll}
\hline No & Persentase & Kategori \\
\hline 1 & $0-20$ & Tidak Praktis \\
\hline 2 & $21-40$ & Kurang Praktis \\
\hline 3 & $41-60$ & Cukup Praktis \\
\hline 4 & $61-80$ & Praktis \\
\hline 5 & $81-100$ & Sangat Praktis \\
\hline
\end{tabular}

Sumber : (Riduwan, 2013)

\section{Hasil dan Pembahasan}

\section{Hasil Penelitian} dari:

Berikut langkah langkah yang digunakan dalam mengembangkan instrumen penilaian

\section{Tahap Define (Pendefinisian)}

Dalam tahap Pendefinisian guru melakukan diagnosis terhadap pembelajaran sosiologi kelas XI SMAN 1 Linggo Sari Baganti, kemudian menentukan kebutuhan untuk meningkatkan efektifitas dalam proses pembelajaran. Peneliti mempelajari karakteristik, menganalisis tugastugas pokok yang harus dikuasai oleh, menganalisis konsep akan diajarkan dan perubahan perilaku yang diharapkan dalam sebuah pembelajaran.

Dalam konteks pengembangan instrumen penilaian diri ini tahap Pendefinisian dilakukan dengan cara berikut:

a. Analisis Kurikulum

Analisis Kurikulum merupakan tahap untuk mengkaji kurikulum yang berlaku di SMAN 1 Linggo Sari Baganti. Untuk melakukan analisis kurikulum peneliti melakukan observasi dan wawancara. Berdasarkan hasil observasi dan wawancara yang dilakukan, bahwa proses pembelajaran sosiologi dimasa Covid19 di kelas XI IPS SMAN 1 Linggo Sari Baganti yaitu : kurikulum yang berlaku di SMAN 1 Linggo Sari Baganti ialah kurikulum 2013, RPP yang digunakan oleh guru yang ada di SMAN 1 Linggo Sari Baganti adalah RPP satu lembar, Bahan ajar yang digunakan adalah LKS (lembar kerja ) yang terdiri dari materi yang dipelajari pada semester genap dan bebera uji kompetensi yang telah disediakan, proses pembelajaran di masa Covid19 adalah dengan sistem Pembelajaran dibagi menjadi dua kelompok on dan off. Artinya jika satu kelompok dalam satu kelas belajar secara luring maka minggu depan mereka belajar di rumah dan kelompok lainnya yang belajar secara luring. Alokasi waktu dalam proses 
pembelajaran kurang dari biasanya, dan penilaian dilakukan hanya berdasarkan tugas , ulangan harian dan ujian semester.

Berdasarkan analisis kurikulum ini peneliti menetapkan bahwa kompetensi inti (KI 1) yang akan dikembangkan adalah Menghayati dan mengamalkan ajaran agama yang dianutnya, dengan kompetensi dasar yaitu KD 3.4 Menganalisis konflik sosial dan cara memberikan respons konflik demi tercapainya kehidupan yang damai di masyarakat, serta indikator pencapaian kompetensi yang dikembangkan instrumen penilaian dirinya adalah 3.4.9 Menganalisis resolusi konflik.

b. Analisis Karakteristik

Analisis karakteristik bertujuan untuk mengenali karakter, oleh sebab itu Peneliti harus mengetahui karakteristik yang ada di kelas XI IPS 1 SMAN 1 Linggo Sari Baganti. Hal tersebut sangat dibutuhkan karna semua proses pembelajaran harus sesuai dengan karakteristik, analisis tersebut dilakukan dengan observasi dalam proses pembelajaran di kelas. Berdasarkan hasil observasi peseta didik kelas XI IPS 1 SMAN 1 Linggo Sari Baganti lebih terbiasa belajar dengan mendengarkan penjelasan materi dari guru, meringkas materi yang penting di LKS dan buku cetak, dan mengerjakan tugas-tugas di LKS yaitu uji kompetensi, soal objektif atau penilaian harian yang sudah ada di LKS. Dari observasi tersebut didapatkan bahwa karakteristik di SMAN 1 Linggo Sari Baganti hanya menerima materi dari guru dan penilaian harian hanya didapatkan dari tugas-tugas yang diberikan oleh guru. Berdasarkan permasalahan di atas peneliti akan merancang rencana pelaksanaan pembelajaran tatap muka dengan model dicsovery learning, dimana dalam rencana pelaksanaan pembelajaran tersebut guru akan memberikan sebuah LKPD, didalam LKPD tersebut terdapat sintak dari discovery learning yaitu akan mengamati sebuh gambar, mengidentifikasi, mengumpulkan data, mengolah data, membuktikan dan menyimpulkan dan diakhir pembelajaran peneliti akan memberikan instrumen penilaian diri untuk mengukur aspek sikap spritual .

\section{c. Analisis Materi}

Analisis materi bertujuan untuk mengidentifikasi materi utama yang perlu diajarkan pada materi konflik sosial dengan menyusun secara sistematis dan merinci dengan materi yang diajarkan serta mengaitkan materi yang satu dengan materi lain. Sehingga membentuk sebuah peta konsep sebagai pedoman materi yang akan diajarkan dalam proses pembelajaran. Berikut ini secara keseluruhan peta konsep materi konflik.

Dalam materi yang telah disajikan tersebut maka akan dilakukan berbagai penilaian dalam proses pembelajaran yaitu dalam penilaian aspek kognitif, afektif dan psikomotor. Dari materi yang telah disajikan, peneliti memilih kompetensi dasar 3.4 konflik sosial, pada indikator pencapaian kompetensi 3.4.9 resolusi konflik dalam mengembangkan instrumen penilaian diri.

\section{d. Analisis Tujuan Pembelajaran}

Setelah melakukan analisis kurikulum, karakteristik dan materi kemudian dilakukan analisis tujuan pembelajaran yaitu peserta dapat mencapai materi yang telah diajarkan oleh guru. Melalui kegiatan pembelajaran diharapkan dapat mencapai tujuan dari materi, dengan cara menganalisis resolusi konflik melalui gambar yang telah diberikan oleh peneliti di dalam LKPD. Tujuan dalam pembelajaran ialah harus memiliki karakter, hal tersebut sesuai dengan apa yang telah dijelaskan dalam kurikulum 2013 bahwa pendidikan karakter dapat diintegrasikan dalam seluruh pembelajaran pada setiap bidang studi yang terdapat dalam kurikulum. Dari penjelasan tersebut maka perlu dikembangkan instrumen penilaian diri yang berbasis karakter. Karakter yang dikembangkan oleh peneliti ialah tiga karakter dari 18 karakter yaitu : ketaatan dalam melaksanakan ibadah, ketaatan dalam melaksanakan ajaran agama dan toleransi beragama. 


\section{Tahap Design (Perancangan)}

Dalam melakukan pengembangan instrumen penilaian diri yang berbasis karakter yaitu ketaatan dalam melaksanakan ibadah, ketaatan dalam melaksanakan ajaran agama dan toleransi beragama. Dalam proses pengembangan produk ini, juga disertai dengan rancangan perangkat pembelajaran yaitu, RPP (rencana pelaksanaan pembelajaran), LKPD (Lembar Kerja) dan soal. Berikut tahap perancangan produk yang dikembangkan.

\section{a. Perancangan Rencana Pelaksanaan Pembelajaran}

Komponen dalam RPP yang dirancang pada penelitian ini terdiri atas: identitas, tujuan pembelajaran, kompetensi dasar dan indikator pencapaian kompetensi, metode pembelajaran, media pembelajaran, langkah-langkah pembelajaran, sumber belajar dan penilaian hasil belajar, yang digunakan dan format RPP yang sesuai dengan kurikulum 2013, yang menggunakan model model discovery learning mengikuti sintak discovery learning. Sintak yang ada dalam discovery learning yaitu: simulation (memberi rangsangan), problem statement (mengidentifikasi masalah), data collection (pengumpulan data), data processing (pengolahan data), verification (pembuktian), generalization (menarik kesimpulan). Sintak generalization (menarik kesimpulan) yang dipilih oleh peneliti dalam melakukan penilaian diri karena pada sintak itulah telah selesai mempelajari materi resolusi konflik.

\section{b. Perancangan Lembar Kerja}

Salah satu perangkat yang disiapkan pada tahap perancangan produk adalah LKPD yang dirancang dengan memuat aspek kompetensi inti, kompetensi dasar dan indikator pencapaian kompetensi, alat dan bahan, petunjuk belajar, informasi pendukung, peta konsep dan aktifitas individu. LKPD yang dibuat oleh peneliti menggunakan model Discovery Learning. Perancangan LKPD tidak dilanjutkan ke tahap Validasi baik itu oleh dosen maupun guru sosiologi. Pada penelitian ini LKPD yang dirancang adalah untuk membantu dalam mengerjakan penugasan.

\section{c. Perancangan Instrumen Penilaian Diri}

Kisi-kisi pada instrumen penilaian diri memiliki kompetensi inti menghayati dan mengamalkan ajaran agama yang dianutnya pada kompetensi dasar memperdalam nilai agama yang dianutnya dan mengamati agama lain, indikator pencapaian kompetensi yaitu memperdalam nilai agama yang dianutnya dan saling menghargai dan menghormati keberagaman agama dalam kehidupan bermasyarakat, materi konflik sosial masyarakat dan indikator yang dipilih untuk menilai instrumen penilaian diri ada tiga yaitu ketaatan dalam melaksanakan ibadah, ketaatan dalam melaksanakan ajaran agama dan toleransi beragama. Berikut kisi-kisi instrumen penilaian diri yang dikembangkan untuk mengukur tiga karakter tersebut

\section{Tabel 3. Aspek Instrumen Penilaian Diri}

\begin{tabular}{|c|c|c|c|}
\hline No & Indikator & Deskriptor & Jumlah \\
\hline \multirow[t]{3}{*}{1.} & \multirow{3}{*}{$\begin{array}{l}\text { Ketaatan dalam } \\
\text { melaksanakan } \\
\text { ibadah }\end{array}$} & Menjalankan ibadah karena adanya dorongan dalam diri sendiri & \multirow[t]{3}{*}{3} \\
\hline & & Menjalankan ibadah karna adanya dorongan dari keluarga, & \\
\hline & & $\begin{array}{l}\text { Menjalankan ibadah hanya pada momentum tertentu dalam } \\
\text { agama }\end{array}$ & \\
\hline \multirow[t]{4}{*}{2.} & \multirow{4}{*}{$\begin{array}{l}\text { Ketaatan dalam } \\
\text { melaksanakan } \\
\text { ajaran agama }\end{array}$} & $\begin{array}{l}\text { Berdoa sebelum pelajaran Sosiologi dilaksanakan membuat saya } \\
\text { semangat dalam belajar }\end{array}$ & \multirow[t]{4}{*}{18} \\
\hline & & $\begin{array}{l}\text { Berdoa setelah selesai melaksanakan pembelajaran yaitu agar } \\
\text { ilmu yang diberikan oleh guru dapat dipahami dengan baik }\end{array}$ & \\
\hline & & $\begin{array}{l}\begin{array}{l}\text { Saya selalu membaca Asmaul Husnah saat memulai } \\
\text { pembelajara, }\end{array} \\
\end{array}$ & \\
\hline & & Saya mengucapkan salam pada saat awal pembelajaran & \\
\hline
\end{tabular}

Jurnal Sikola: Jurnal Kajian Pendidikan dan Pembelajaran Vol. 2, No. 4, Th. 2021 


\begin{tabular}{|c|c|c|c|}
\hline & & \multirow{2}{*}{$\begin{array}{l}\text { sosiologi, } \\
\begin{array}{l}\text { Saya mengucapkan salam pada saat akhir pembelajaran } \\
\text { sosiologi }\end{array}\end{array}$} & \\
\hline & & & \\
\hline & & \multirow{2}{*}{$\begin{array}{l}\text { Saya selalu memberi salam, sebelum dan sesudah } \\
\text { menggungkapkan pendapat, } \\
\text { Bagi saya saat kita menggungkapkan pendapat tidak perlu } \\
\text { memberi salam karna sebelum pembelajaran dimulai kita sudah } \\
\text { mengucapkan salam }\end{array}$} & \\
\hline & & & \\
\hline & & $\begin{array}{l}\text { Saya bersabar dalam mengikuti kegiatan pembelajaran yang } \\
\text { sedang berlangsung dengan memperhatikan penjelasan guru } \\
\text { atau teman secara seksama, }\end{array}$ & \\
\hline & & $\begin{array}{l}\text { Saya cendrung tidak memilih teman pada saat berdiskusi } \\
\text { tentang materi konflik sosial dalam masyarakat }\end{array}$ & \\
\hline & & $\begin{array}{l}\text { Saya tidak akan menggangu teman saat memberikan tanggapan } \\
\text { tentang bagaimana upaya penyelesaian konflik tersebut }\end{array}$ & \\
\hline & & $\begin{array}{l}\text { Saya tidak akan menggangu teman saat memberikan tanggapan } \\
\text { tentang bagaimana upaya penyelesaian konflik tersebut }\end{array}$ & \\
\hline & & $\begin{array}{l}\text { Saya akan menerima bahwa pendapat saya tentang upaya } \\
\text { penyelesaian konflik pada kasus tersebut kurang tepat }\end{array}$ & \\
\hline & & $\begin{array}{l}\text { Saya akan membantu teman dalam memahami materi konflik } \\
\text { sosial pada minggu lalu karena teman tersebut tidak hadir pada } \\
\text { pertemuan sebelumnya }\end{array}$ & \\
\hline & & $\begin{array}{l}\text { Saya lebih suka meminjamkan buku pada teman dari pada } \\
\text { memiliki buku sumber sendiri tentang materi konflik social }\end{array}$ & \\
\hline & & $\begin{array}{l}\text { Tidak mengejek teman yang tidak bisa memberikan kesimpulan } \\
\text { tentang materi konflik social }\end{array}$ & \\
\hline & & $\begin{array}{l}\text { Menegur teman yang tidak serius pada saat memberikan contoh } \\
\text { bagaiamana upaya penyesaian konflik yang tepat pada kasus } \\
\text { tersebut }\end{array}$ & \\
\hline & & \multicolumn{2}{|l|}{$\begin{array}{l}\text { Membiarkan saja teman tidak serius memberikan contoh } \\
\text { bagaiamana upaya penyesaian konflik yang tepat pada kasus } \\
\text { tersebut, }\end{array}$} \\
\hline & & \multicolumn{2}{|l|}{$\begin{array}{l}\text { Menegur teman yang mengejek pendapat dari teman lain saat } \\
\text { berdiskusi tentang konflik social }\end{array}$} \\
\hline \multirow{4}{*}{\multicolumn{2}{|c|}{$\begin{array}{r}\text { Toleransi } \\
\text { beragama }\end{array}$}} & $\begin{array}{l}\text { Saya bersedia berteman dan berkerja sama dengan teman yang } \\
\text { berbeda agama }\end{array}$ & 4 \\
\hline & & $\begin{array}{l}\text { Saya tidak pernah membedakan teman dalam memberikan } \\
\text { pendapat dan berkerja sama dalam mencari solusi atau upaya } \\
\text { dalam penyelesaian konflik }\end{array}$ & \\
\hline & & $\begin{array}{l}\text { Saya berteman dan berkerja sama dengan teman yang berbeda } \\
\text { agama apabila dipaksa oleh guru }\end{array}$ & \\
\hline & & \multicolumn{2}{|l|}{$\begin{array}{l}\text { Saya menolak berteman dengan orang yang berbeda agama } \\
\text { walaupun dipaksa oleh guru }\end{array}$} \\
\hline
\end{tabular}

Instrumen penilaian diri tersebut dikembangkan dengan melihat karakter apa yang bisa diintegrasikan dengan materi resolusi konflik. Tujuan dari pengembangan instrumen penilaian diri ialah guru sosiologi memiliki instrumen penilaian diri pada kompetensi dasar konflik sosial. Dengan adanya instrumen penilaian diri bisa melakukan penilaian terhadap diri mereka sendiri. instrumen ini sangat memudahkan guru dalam melakukan penilaian sikap. Disebabkan guru memiliki instrumen yang efektif dalam melakukan penilaian. Tidak lagi terfokus pada penilaian observasi, jurnal dan teman sejawat. Berikut ini bentuk desain instrumen penilaian diri yang dikembangkan pada tiga indikator dari karakter. 
Aulia Putri Wandia, Ike Sylvia Pengembangan Instrumen Penilaian Diri (Self Assesment) Untuk Menilai Karakter Spritual Pada Pembelajaran Sosiologi Kelas XI SMA

Tabel 4. Desain Instrumen Penilaian Diri
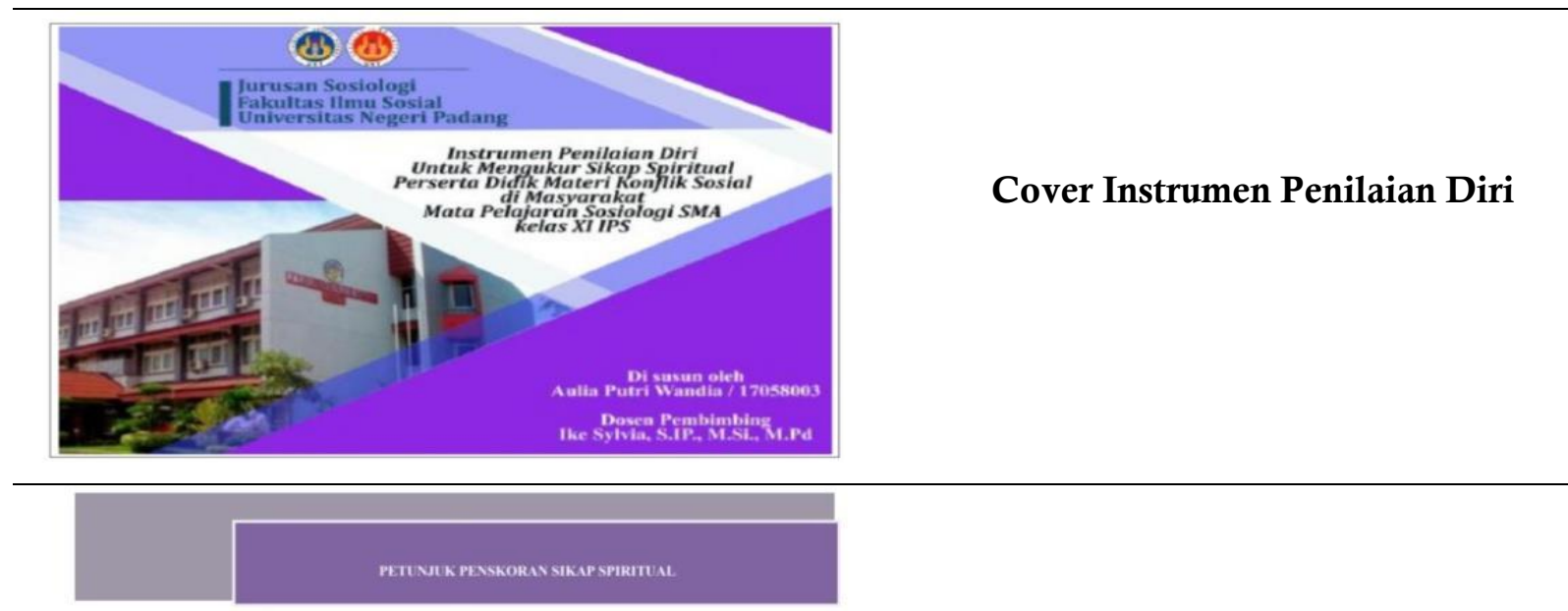

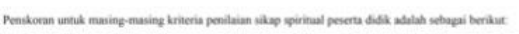

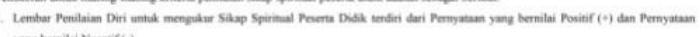

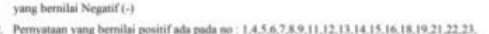

Petunjuk Penskoran

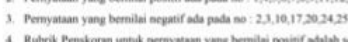

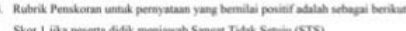

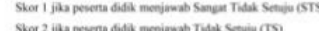

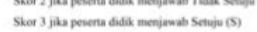

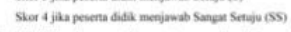

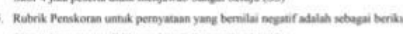

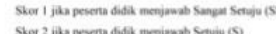

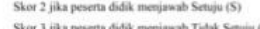

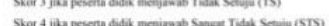

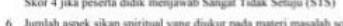
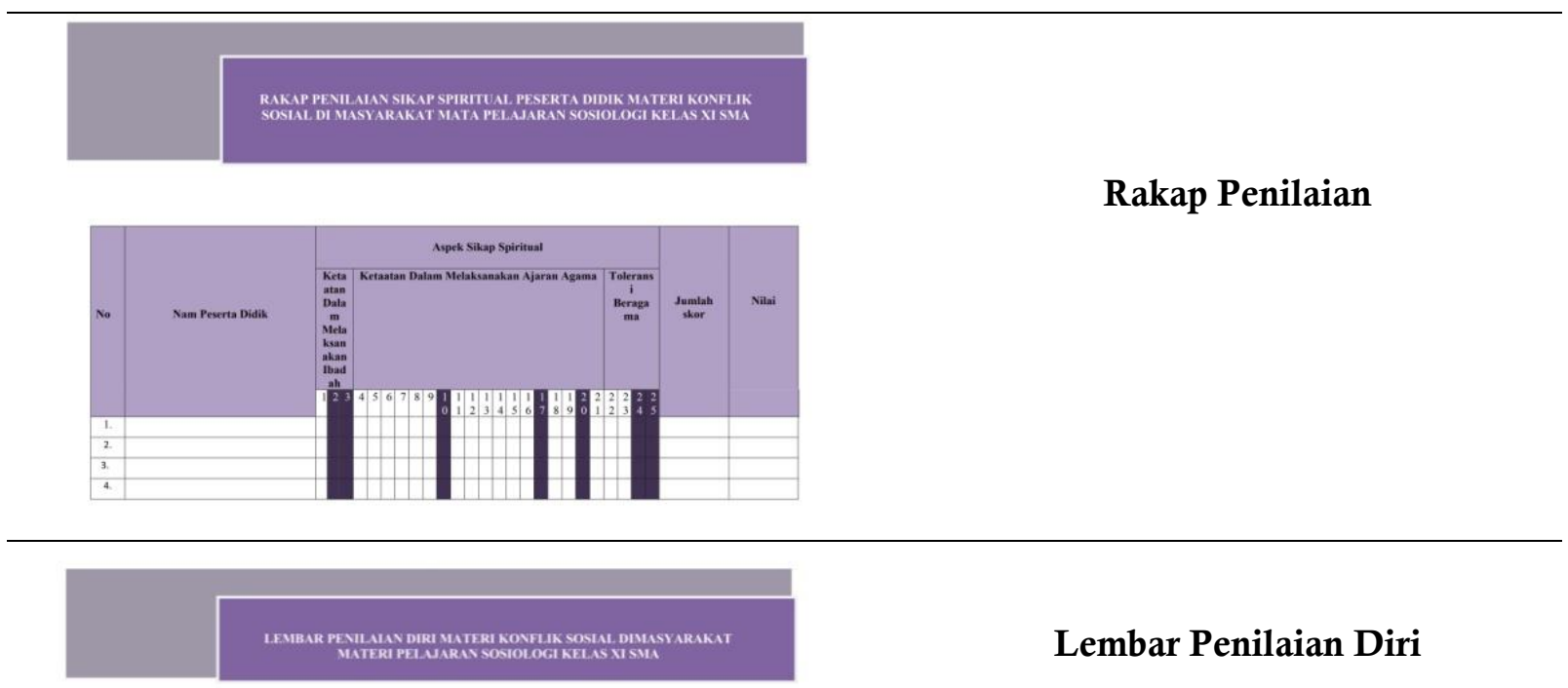

Lembar Penilaian Diri

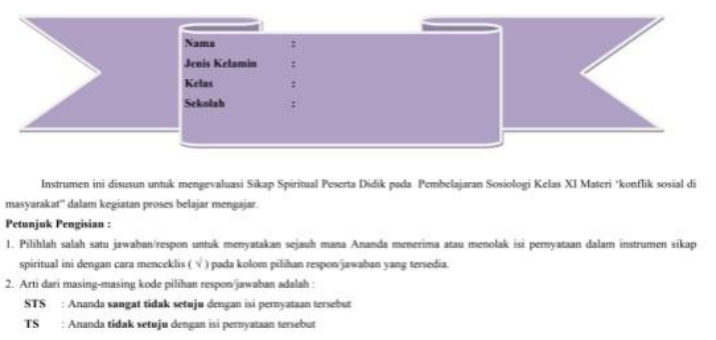

Sumber: Data Primer 2021

Jurnal Sikola: Jurnal Kajian Pendidikan dan Pembelajaran Vol. 2, No. 4, Th. 2021

ISSN. 2715-1735

Copyright@2021, by Author 


\section{d. Perancangan Soal}

Perancangan soal dilakukan untuk melihat hasil pretest dan postest. Materi yang digunakan ialah resolusi konflik, banyak soal yang digunakan untuk menilai hasil pretest and posttest adalah 20 soal, masing-masing soal memiliki tujuan pembelajaran dan kerangka berfikir.

\section{Tahap Develop (Pengembangan)}

Pada tahap ini peneliti melakukan uji validasi yang diberikan dengan cara memberikan instrumen validasi dan produk pengembangan untuk dinilai oleh ahli/pakar.

a. Hasil Validasi Rencana Pelaksanaan Pembelajaran

Tabel berikut menggambarkan hasil validasi RPP dari tiga orang pakar/ahli

Tabel 5. Hasil Aspek Penilaian Dari Validasi RPP

\begin{tabular}{clcc}
\hline No & \multicolumn{1}{c}{ Aspek Penilaian } & Nilai Validasi & \multicolumn{1}{c}{ Keterangan } \\
\hline 1. & Aspek identitas & 0,994 & Validitas sangat tinggi \\
\hline 2. & Aspek tujuan pembelajaran & 0,912 & Validitas sangat tinggi \\
\hline 3. & Aspek KD dan IPK & 0,912 & Validitas sangat tinggi \\
\hline 4. & Metode pembelajaran & 0,810 & Validitas sangat tinggi \\
\hline 5. & Media pembelajaran & 0,994 & Validitas sangat tinggi \\
\hline 6. & Langkah-langkah & 0,994 & Validitas sangat tinggi \\
\hline 7. & Penilaian hasil pembelajaran & 0,994 & Validitas sangat tinggi \\
\hline & Rata-rata & 0,944 & Validitas sangat tinggi \\
\hline
\end{tabular}

\section{Sumber: Data Primer 2021}

Dari tabel di atas dapat dilihat bahwa setiap aspek memiliki hasil validasi yang berbedabeda, walaupun pada aspek identitas, media, langkah-langkah dan penilaian memiliki penilaian yang sama. Tidak hanya aspek itu saja aspek tujuan dan KD dan IPK juga memiliki aspek yang sama. Biarpun hasil validasi memiliki persamaan dan perbedaan dalam setiap aspek, tetapi hasil validasi memiliki keterangan yang sama yaitu sangat tinggi. Keterangan validasi sangat tinggi tersebut ditentukan dari interpretasi kolelasi yang mengatakan bahwa dari 0,80-1.00 dikatakan sangat tinggi.

b. Hasil Validasi Instrumen Penilaian Diri

Validasi produk dilakukan oleh tiga orang ahli. Berikut merupakan analisis hasil validasi produk instrument penilaian diri menurut para ahli

Tabel 6. Hasil Aspek Penilaian Validasi Produk

\begin{tabular}{llll}
\hline No & Aspek Penilaian & Nilai Validasi & Keterangan \\
\hline 1. & Aspek instrumen/ isi & 0,993 & Validitas sangat tinggi \\
\hline 2. & Aspek tujuan pembelajaran & 0,993 & Validitas sangat tinggi \\
\hline 3. & Aspek objektifitas & 0,993 & Validitas sangat tinggi \\
\hline 4. & Aspek kesistematisan & 0,993 & Validitas sangat tinggi \\
\hline 5. & Aspek Konstruksi & 0,993 & Validitas sangat tinggi \\
\hline 6. & Aspek Kegrafikan & 0,993 & Validitas sangat tinggi \\
\hline 7. & Aspek Kepraktisan & 0,917 & Validitas sangat tinggi \\
\hline & rata-rata & 0,982 & Validitas sangat tinggi \\
\hline
\end{tabular}

Sumber: Data Primer 2021 
Dari tabel di atas dapat dilihat bahwa setiap aspek memiliki hasil validasi yang berbedabeda, walaupun dari aspek instrumen sampai dengan kegrafikan memiliki hasil validasi yang sama tetap pada aspek kepraktisan memiliki hasil validasi yang berbeda. Biarpun hasil validasi memiliki persamaan dan perbedaan dalam setiap aspek, tetapi hasil validasi memiliki keterangan yang sama yaitu sangat tinggi. Keterangan validasi sangat tinggi tersebut ditentukan dari interpretasi kolelasi yang mengatakan bahwa dari 0,80-1.00 dikatakan sangat tinggi.

c. Hasil Validasi Soal

Validasi soal dilakukan oleh tiga orang ahli/pakar, yang terdiri dari 1 orang pakar materi, evaluasi dan desai pembelajaran.

Tabel 7. Hasil Aspek Penilaian Validasi Soal

\begin{tabular}{clcl} 
No & \multicolumn{1}{c}{ Aspek } & $\begin{array}{c}\text { Nilai } \\
\text { Validasi }\end{array}$ & \multicolumn{1}{c}{ Keterangan } \\
\hline 1. & Tingkat Kesulitan soal & 0,884 & Validitas sangat tinggi \\
\hline 2. & Tingkat kejelasan rumusan soal & 0,884 & Validitas sangat tinggi \\
\hline 3. & Tingkat kejelasan rumusan pilihan jawaban & 0,884 & Validitas sangat tinggi \\
\hline 4. & Tingkat kesusaian butir soal & 0,846 & Validitas sangat tinggi \\
\hline 5. & Kelengkapan materi & 0,846 & Validitas sangat tinggi \\
\hline 6. & Keluasan materi & 0,884 & Validitas sangat tinggi \\
\hline 7. & Keakuratan konsep dan materi & 0,846 & Validitas sangat tinggi \\
\hline 8. & Keakuratan data dan fakta materi & 0,884 & Validitas sangat tinggi \\
\hline 9. & Kesesuaian contoh & 0,846 & Validitas sangat tinggi \\
\hline 10. & Kegunaan contoh & 0,884 & Validitas sangat tinggi \\
\hline 11. & Tingkat keterbacaan & 0,884 & Validitas sangat tinggi \\
\hline 12. & Tingkat pemahaman & 0,846 & Validitas sangat tinggi \\
\hline 13. & Tingkat kebahasaan & 0,884 & Validitas sangat tinggi \\
\hline 14. & Tingkat keseimbangan & 0,846 & Validitas sangat tinggi \\
\hline 15. & Kesesuaian tingkat level kognitif soal & 0,846 & Validitas sangat tinggi \\
\hline & Rata-rata & 0,866 & Validitas sangat tinggi \\
\hline Sum & Data Primer 2021 &
\end{tabular}

Sumber: Data Primer 2021

Dari tabel di atas dapat dilihat bahwa setiap aspek memiliki hasil validasi yang berbedabeda, walaupun pada aspek dari aspek tingkat kesulitan soal, tingkat kejelasan rumusan soal, tingkat kejelasan rumusan pilihan jawaban, kelengkapan materi, keakuratan data dan fakta materi, kegunaan contoh, tingkat keterbacaan, tingkat kebahasaan memiliki hasil validasi yang sama tetap pada aspek tingkat kesusaian butir soal, keluasan materi, keakuratan konsep dan materi, kesesuaian contoh, tingkat pemahaman, tingkat keseimbangan dan kesesuaian tingkat level kognitif soal memiliki nilai validasi yang sama. Biarpun hasil validasi memiliki persamaan dan perbedaan dalam setiap aspek, tetapi hasil validasi memiliki keterangan yang sama yaitu sangat tinggi. Keterangan validasi sangat tinggi tersebut ditentukan dari interpretasi kolelasi yang mengatakan bahwa dari 0,80-1.00 dikatakan sangat tinggi.

\section{Tahap Disseminate (Penyebarluasan)}

a. Proses Pembelajaran.

Model yang digunakan dalam rencana pelaksanaan pembelajaran ialah model discovery learning, dengan menggunakan model discovery learning maka peneliti harus menjalankan proses pembelajaran sesuai dengan sintak discovery learning. Pada tahap pertama peneliti memberikan

Jurnal Sikola: Jurnal Kajian Pendidikan dan Pembelajaran Vol. 2, No. 4, Th. 2021 
stimulus kepada dengan memberikan soal pretest kepada dan memberikan waktu kepada untuk menyelesaikan soal pretest, guru menempelkan sebuah gambar dipapan tulis tentang resolusi konflik, guru meminta untuk mengamati gambar resolusi konflik, guru meminta untuk menjelaskan gambar resolusi konflik.

Tahap kedua mengidentifikasi, guru memberikan kesempatan kepada untuk mengidentifikasi gambar resolusi konflik yang ada dipapan tulis. Tahap ketiga pengumpulan data, melakukan pengumpulan data tentang pengertian dan syarat resolusi konflik. Tahap keempat pengolahan data Informasi yang diperoleh tentang resolusi konflik dapat menjawab pengertian dan syarat resolusi konflik (Kolaborasi, kolaborasi, menghindari, akomodasi dan kompromi). Tahap kelima pembuktian mendiskusikan hasil pengolahan data dengan memverifikasi hasil pengolahan dengan data-data pada sumber terkait materi yang disajikan, guru memberikan kesempatan kepada untuk mempersentasikan apa yang telah didapatkan tentang pengertian dan syarat upaya penyelesaian konflik (Kolaborasi, kolaborasi, menghindari, akomodasi dan kompromi). Tahap keenam menarik kesimpulan guru bersama menyimpulkan pengertian dan syarat upaya penyelesaian konflik (kolaborasi, kolaborasi, menghindari, akomodasi dan kompromi), ini proses dalam pembelajaran yang dilakukan pada minggu ke sembilan pada shift A dan B.

Pada pertemuan ke sepuluh peneliti juga menggunakan model discovery learning, pada tahap pertama guru memberikan stimulus dengan memberikan sebuah LKPD kepada, guru meminta untuk mengamati gambar yang ada di LKPD, dan guru meminta untuk mengamati gambar yang ada di LKPD. Tahap kedua mengidentifikasi guru memberikan kesempatan kepada untuk mengidentifikasi contoh resolusi konflik yang ada di LKPD. Tahap ketiga pengumpulan data melakukan pengumpulan informasi tentang resolusi konflik yang telah di pelajari pada pertemuan sebelumnya, supaya dapat menjawab contoh upaya penyelesaian konflik yang ada di LKPD, tahap keempat pengolahan data Informasi yang diperoleh tentang resolusi konflik dapat menjawab resolusi apakah yang cocok untuk mengatasi permasalahan konflik yang ada di gambar. Tahap kelima pembuktian dengan mendiskusikan hasil pengolahan data dengan memverifikasi hasil pengolahan dengan data-data pada sumber terkait materi yang disajikan dan tahap keenam guru bersama menyimpulkan materi resolusi konflik, guru membagikan soal posttest kepada masing-masing, guru memberi waktu peserta untuk menjawab pertanyaan, guru memberikan instrumen penilaian diri dan guru memberikan kesempatan kepada untuk mengisi instrumen penilaian diri.

\section{b. Hasil Uji Coba Instrumen Penilaian Diri}

Instrumen penilaian diri yang telah divalidasi dan direvisi berdasarkan saran ahli, kemudian diujicobakan kepada 35 di kelas XI IPS 1 SMAN 1 Linggo Sari Baganti. Hasil uji coba tersebut dinilai oleh peneliti dengan menggunakan rumus instrumen penilaian diri yang telah ditentukan. Berikut hasil uji coba instrumen penilaian diri.

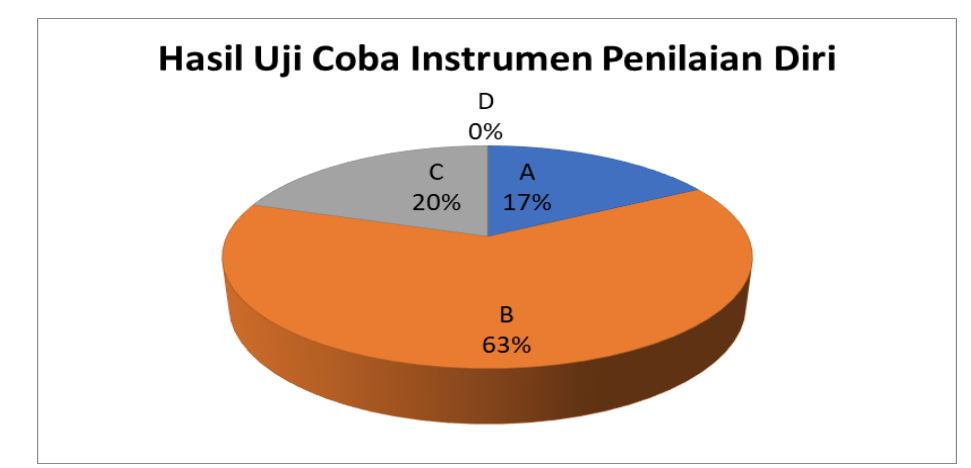

Gambar 5. Grafik Hasil Uji Coba Instrumen Penilaian Diri Sumber: Data Primer 2021

Jurnal Sikola: Jurnal Kajian Pendidikan dan Pembelajaran Vol. 2, No. 4, Th. 2021 
Dari grafik tersebut dapat dilihat bahwa nilai kelas XI IPS 1 SMAN 1 Linggo Sari Baganti yaitu: mendapatkan nilai A sebanyak $17 \%$, nilai B $63 \%$, nilai C $20 \%$ dan nilai D $0 \%$. Nilai A memiliki rentang nilai $85<\mathrm{N} \leq 100$, nilai $\mathrm{B}$ memiliki rentang nilai $70<\mathrm{N} \leq 85$, nilai $\mathrm{C}$ memiliki rentang nilai $55<\mathrm{N} \leq 70$ dan nilai $\mathrm{D}$ memiliki rentang nilai $\leq 55$ (Direktorat Pembinaan SMA Ditjen Pendidikan Dasar dan Menengah 2017: 11). Maka dari itu kelas XI IPS 1 SMAN 1 Linggo Sari Baganti yang mendapatkan nilai A sebanyak enam, nilai B 22, nilai C tujuh dan nilai $\mathrm{D} 0$.

c. Hasil Uji Efektifitas soal

Untuk melihat efektivitas instrumen penilaian diri yang dikembangkan dapat dilihat dari pemberian soal pretest dan posttest yang kemudian dianalisis dengan program SPSS versi 26 Analyze Paired-Sample T-Test. Secara ringkas untuk melihat hasil pretest dan posttest dapat dilihat pada tabel berikut ini.

Tabel 7. Hasil Uji Coba Efektifitas

\begin{tabular}{|c|c|c|c|c|c|c|c|c|}
\hline \multicolumn{9}{|c|}{ Paired Samples Test } \\
\hline & \multicolumn{5}{|c|}{ Paired Differences } & \multirow{3}{*}{$\mathrm{t}$} & \multirow{3}{*}{ Df } & \multirow{3}{*}{$\begin{array}{l}\text { Sig. (2- } \\
\text { tailed) }\end{array}$} \\
\hline & \multirow[t]{2}{*}{ Mean } & \multirow[t]{2}{*}{$\begin{array}{c}\text { Std. } \\
\text { Deviation }\end{array}$} & \multirow{2}{*}{$\begin{array}{l}\text { Std. } \\
\text { Error } \\
\text { Mean }\end{array}$} & \multicolumn{2}{|c|}{$\begin{array}{l}95 \% \text { Confidence } \\
\text { Interval of the } \\
\text { Difference }\end{array}$} & & & \\
\hline & & & & Lower & Upper & & & \\
\hline $\begin{array}{ll}\text { Pair } & \text { PreTest - } \\
1 & \text { Post Test }\end{array}$ & $-28,85714$ & 13,23352 & 2,23687 & $\begin{array}{c}- \\
33,40302\end{array}$ & 24,31127 & $\begin{array}{c}- \\
12,901\end{array}$ & 34 &, 000 \\
\hline
\end{tabular}

Sumber: Data Primer 2021

Dari hasil pretest and posttest didapati Sig (2-tailed) yaitu 0.00 berarti $<0,05$ berarti terdapat perbedaan yang signifikan antara hasil belajar pretest dan posttest.

\section{d. Hasil Praktikalitas produk}

Setelah melakukan validasi oleh beberapa ahli, maka produk diuji cobakan kepada 35 kelas XI IPS 1 dan satu orang guru sosiologi yaitu Ibu FY yang melakukan uji coba untuk menggunakan rumus yang ada di instrumen yang dikembangkan untuk melakukan penilaian afektif. Dari uji coba yang dilakukan oleh dan guru maka dapat dilihat apakah instrumen penilaian diri tersebut praktis digunakan dalam penilaian afektif untuk mengukur sikap religius. Berikut hasil praktiklaitas instrumen penilaian diri.

Tabel 8. Hasil Aspek Penilaian Praktikalitas Produk

\begin{tabular}{clcl}
\hline No & \multicolumn{1}{c}{ Aspek Penilaian } & Presentase & Keterangan \\
\hline 1 & Objektif & $87 \%$ & Sangat Praktis \\
\hline 2 & Bentuk lembar penilaian & $88 \%$ & Sangat Praktis \\
\hline 3 & Efektif & $89 \%$ & Sangat Praktis \\
\hline 4 & Bahasa & $87 \%$ & Sangat Praktis \\
\hline 5 & Petujuk pengisian & $87 \%$ & Sangat Praktis \\
\hline 6 & Pedoman Penskoran & $86 \%$ & Sangat Praktis \\
\hline 7 & Penafsiran Ganda & $90 \%$ & Sangat Praktis \\
\hline 8 & Penerapan & $87 \%$ & Sangat Praktis \\
\hline 9 & Menentukan Skor & $86 \%$ & Sangat Praktis \\
\hline 10 & Relevan & $88 \%$ & Sangat Praktis \\
\hline
\end{tabular}

Jurnal Sikola: Jurnal Kajian Pendidikan dan Pembelajaran Vol. 2, No. 4, Th. 2021 
Sumber: Data Primer 2021

Dari tabel di atas dapat dilihat bahwa semua aspek tersebut dapat dikatakan praktis sesuai dengan persentase masing-masing. Dengan semua aspek tersebut mendapatkan keterangan yang sama yaitu: sangat praktis. Maka dari itu instrumen ini dapat digunaka karena praktis dalam aspek pengujian praktikalitas. berikut:

Dari uraian hasil penelitian di atas dapat disimpulkan hasil penelitian ini dalam tabel

Tabel 9. Hasil rakap validitas, efektifitas dan praktikalitas.

\begin{tabular}{ll}
\multicolumn{1}{c}{ Validasi } & \multicolumn{1}{c}{ Rata-Rata } \\
\hline Validasi Produk & 0,982 (Validasi sangat tinggi) \\
\hline Validasi RPP & 0,944 (Validitas sangat tinggi). \\
\hline Validitas Soal & 0,866 (Validasi sangat tinggi) \\
\hline \multicolumn{1}{c}{ Efektivitas } \\
\hline Pretest $\quad 48,8571$ \\
\hline Postest Praktikalitas & 77,7143 \\
\hline T-test & 12,901 \\
\hline \multicolumn{2}{c}{ Angket Guru dan } \\
\hline
\end{tabular}

Sumber: Data Primer 2021

\section{Pembahasan}

Pengembangan sebuah produk dikatakan valid apabila dilakukan secara tepat dan sesuai langkah-langkah yang telah ditentukan. Faktor yang mempengaruhi sebuah valid atau tidaknya sebuah produk tentukan oleh makna dalam sebuah pengembangan sebuah produk tidak jelas, kata-kata dalam sebuah instrumen tersebut sulit untuk dipahami, waktu yang tepat untuk implementasi produk yang dikembangkan dan lain-lain sebagainya. Validasi instrumen penilaian diri dilihat dari hasil validasi yang telah diberikan oleh seorang ahli. Hasil pengembangan suatu produk dikatakan valid jika produk berdasarkan teori yang memadai dan semua komponen produk pembelajaran satu sama lain dan berhubungan secara konsisten. (Sylvia, Anwar, \& Khairani, 2019). Menurut Tulus Pamuji Wicaksono, dkk (Wicaksono, Muhardjito, \& Harsiati, 2016) mengatakan bahwa instrumen penilaian diri tersebut valid digunakan untuk mengukur afektif sesuai dengan hasil validasi yang telah dilakukan.

Peneliti melakukan validasi instrumen penilaian diri, validasi ini dilakukan oleh 3 orang validator yaitu 2 orang dosen dan 1 orang guru sosiologi. Validasi tersebut dilakukan dengan memberikan angket validasi kepada ahli dengan rentang nilai 1 samapi 5. Nilai 1 dengan kategori sangat kurang, 2 dengan kategori kurang, 3 dengan kategori cukup, 4 dengan kategori baik dan 5 dengan kategori sangat baik. Masing-masing aspek memiliki nilai validasi tersendiri, pada aspek instrumen nilai validasi 0,993 , aspek tujuan pembelajaran mendapatkan nilai validasi 0,993, aspek objektifitas mendapatkan nilai validasi 0,993 , aspek kesisematisan mendapatkan nilai 0,993 , aspek konstruksi mendapatkan nilai validasi 0,993 , aspek kegrafikan mendapatkan nilai validasi 0,993 dan aspek kepraktisan mendapatkan nilai validasi 0,917. Maka didapatkan bahwa rata-rata dari validasi tersebut adalah 0,982 (validasi sangat tinggi). Dari penjelasan tersebut dapat kita lihat bahwa instrumen penilaian diri tersebut valid digunakan dalam melakukan penilaian.

\section{Penilaian Praktikalitas Instrumen Penilaian Diri}

Kepraktisan suatu produk ditentukan oleh alat ukur yang digunakan dalam melakukan suatu penilaian. Menurut Zainal Arifin (Z. Arifin, 2009) kepraktisan dalam evaluasi pendidikan 
merupakan kemudahan-kemudahan yang ada pada instrumen evaluasi baik dalam mempersiapkan, menggunakan, menginterpretasikan/ memperoleh hasil maupun kemudahan dalam menyimpannya. Untuk membuktikan suatu instrumen penilaian adalah prktis ditentukan dari hasil penilaian ahli dan paktisi menunjukkan bahwa instrumen penilaian dapat dilaksanakan dan berlangsung sepanjang proses pembelajaran dan hasil observasi di lapangan bahwa dan guru dapat melaksanakan aktivitas yang sesuai dengan aktivitas yang telah dicantumkan oleh RPP. Kepraktisan sebuah instrumen penilaian diri akan terbukti dari hasil yang diungkapkan oleh pengguna.

\section{Penilaian Efektivitas Instrumen Penilaian Diri}

Efektivitas instrumen penilaian diri dapat dilihat berdasarkan hasil pengukuran yang dilakukan dengan memberikan lembar penilaian diri (dalam Tulus Pamuji Wicaksono, dkk 2016). Instrumen penilaian diri tersebut dikatan efektif dari yakin dan percaya akan kemampuan yang mereka miliki dan tuhannya mereka dapat belajar dengan baik dan mengajarkan soal dengan baik. Melihat hasil belajar tersebut dapat dilakukan dengan perbedaan hasil belajar sebelum dilakukannnya pembelajaran (pretest) dan sesudah dilakukannya pembelajaran (postest), perbedaan tersebut dapat dilihat dari peningkatan hasil belajar bisa dilihat dari pemberian soal pretest dan postest yang kemudian dianalisis dengan program SPSS versi 26 Analyze Paired-Sample T-Test. Setelah skor masing-masing dijumlahkan kemudian dianalisis dengan Analyze PairedSample T-Test pada program spss dan diperoleh hasil Sig.(2-tailed) 0.00. Menurut Dewi Priyatno (2010) dalam Retno Fauziah (Fauziah, 2016) dasar pengambilan keputusan hasil analisis t-test adalah Ho diterima jika signifikan $>0,05$ dan Ho ditolak jika signifikan $<0,05$. Ho adalah tidak ada perbedaan yang signifikan antara rata-rata nilai pretest dan rata-rata nilai posttest. Pada penelitian ini dpieroleh hasil Sig.(2-tailed) $0.00<0,05$ jadi dapat disimpulkan terdapat perbedaan antara rata-rata nilai.

\section{Kesimpulan}

Pengembangan instrumen penilaian diri sebagai instrumen untuk mengukur sikap pada pembelajaran sosiologi KD 3.4 konflik sosial dan pada IPK resolusi konflik dengan model 4-D dapat digunakan sebagai mengukur sikap dalam meningkatkan penilaian pada. Produk ini telah divalidasi oleh 3 orang ahli dan menghasilkan rata-rata validitas 0,982 dengan kategori sangat tinggi, sedangkan validasi RPP memperoleh rata-rata validitas 0,944 sangat tinggi dan validasi soal menghasilkan skor rata-rata validitas 0,866 dengan kategori sangat tinggi. Berdasarkan uji efektivitas instrumen penilaian diri dinyatakan efektif dari hasi uji $\mathrm{T}$ dengan bantuan SPSS versi 26 diperoleh hasil Sig (2-tailed) yaitu $0.00<0,05$ yang bermakna bahwa terdapat perbedaan hasil belajar sebelum dilakukan pembelajaran (pretest) dan setelah dilakukannya pembelajaran (posstest). Instrumen penilaian diri yang telah dikembangkan ini telah diujicobakan pada kelas XI IPS 1 SMAN 1 Linggo Sari Baganti dengan hasil uji praktikalitas instrumen penilaian diri dinyatakan sangat praktis dengan skor rata-rata $87 \%$, dengan demikian instrumen penilaian diri yang dikembangkan ini dapat digunakan untuk mengukur sikap, khususnya sikap religius.

\section{Daftar Pustaka}

Alif, A., Nonoh, A. S., \& Sarwanto. (2015). Authentic Assessment Berbasis Scientific Approach Sebagai Implementasi Kurikulum 2013 Abstrak Pendahuluan. Jurnal Inkuri, 4(3), 39-50.

Arifin, R., Kusumah, I. H., \& Mubarak, I. (2018). Hasil Penilaian Diri Dan Penilaian Teman Sebaya Dibandingkan Dengan Assessment Dosen Untuk Hasil Produk Mata Kuliah Body Otomotif. Journal of Mechanical Engineering Education, $5(1), \quad 78$. https://doi.org/10.17509/jmee.v5i1.12623

Arifin, Z. (2009). Evaluasi Pembelajaran. Bandung: PT. Remaja Rosdakarya.

Jurnal Sikola: Jurnal Kajian Pendidikan dan Pembelajaran Vol. 2, No. 4, Th. 2021 
Aulia Putri Wandia, Ike Sylvia Pengembangan Instrumen Penilaian Diri (Self Assesment) Untuk Menilai Karakter Spritual Pada Pembelajaran Sosiologi Kelas XI SMA

Darmadji, A. (2011). Urgensi Ranah Afektif Dalam Evaluasi Pendidikan Agama Islam Di Perguruan Tinggi. Unisia, 33(74), 181-192. https://doi.org/10.20885/ unisia.vol33.iss 74.art7

Fauziah, R. (2016). Efektivitas Penggunaan Modul untuk Meningkatkan Hasil Belajar Mata Pelajaran Boga Dasar Kelas X di SMK Negeri 1 Kalasan Yogyakarta. Universitas Negery Yogyakarta.

Hartati, M. (2010). Penerapan Penilaian Atentik Dalam Upaya Penigkatan Mutu Pendidikan. Jakarta: FIP UNP.

Himatus Sofiya. (2013). Penerapan Self Assement Penilaian Diri pada Kegiatan Praktikum Untuk Meningkatkan Hasil Belajar Siswa Kelas X SMAN 1 Sidayu. Inoveasi Pendidikan Fisika, 2(3), 139-142.

Kemendikbud RI. (2017). Panduan Penilaian oleh Pendidikan dan Satuan Pendikin untuk Sekolah Menengah Atas. Direktorat Pembinaan Sekolah Menengah Atas Direktorat Jenderal Pendidikan dan Kebudayaan. Jakarta: Kemendikbud RI.

Lutasari, S. (2018). Pengembangan Instrumen Penilaian Kinerja Siswa Pada Pembelajaran Pratikum Fisika SMA. Universitas Negeri Yogyakarta.

Menteri Pendidikan Dan Kebudayaan RI. Permendikbud No 66 Tahun 2013 tentang Standar Penilaian Pendidikan. , (2013).

Muawwan, K. A. (2018). Pengembangan Instrumen Penilaian Diri Pada Sikap Sosial Untuk Pembelajaran Berbasis Masalah Pada Mata Pelajaran Pendidikan Agama Islam. UIN Sunan Ampel Surabaya.

Mulyasa, M. (2003). Kurikulum Barbasis Kompetensi. Bandung: Remaja Rosdakarya.

Nurgiyantoro, B. (2010). Penilaian Pembelajaran Bahasa Berbasis Kompetensi Edisi 2. Yogyakarta: BPFE Yogyakarta.

Riduwan, R. (2013). Skala Pengukuran Variabel-Variabel Penelitian. Bandung: Alfabeta.

Saftari, M., \& Fajriah, N. (2019). Penilaian Ranah Afektif Dalam Bentuk Penilaian Skala Sikap Untuk Menilai Hasil Belajar. Edutainment: Jurnal Ilmu Pendidikan Dan Kependidikan, 7(1), 71-81. https://doi.org/10.35438/e.v7i1.164

Sani, R. A. (2016). Penilaian Autentik. Jakarta: PT. Bumi Aksara.

Sylvia, I., Anwar, S., \& Khairani, K. (2019). Pengembangan Instrumen Penilaian Autentik Berbasis Pendekatan Authentic Inquiry Learning Pada Mata Pelajaran Sosiologi di Sekolah Menengah Atas. Socius, 6(2), 103-120. https://doi.org/10.24036/scs.v6i2.162

Wicaksono, T. P., Muhardjito, M., \& Harsiati, T. (2016). Pengembangan Penilaian Sikap dengan Teknik Observasi, Self Assesment, dan Peer Assesment Pada pembelajaran Tematik Kelas V SDN Arjowinagun 02 Malang. Pendidikan: Teori Dan Pengembangan, 1(1), $45-51$.

Wijayanti, A. (2017). Assessment Dalam Pembentukan Karakter Siswa. Realita, 15(2), 1-14.

Winarni, E. W. (2018). Teori dan Praktik Penelitian Kuantitatif, Kualitatif, PTK, R\&D. Jakarta: Bumi Aksara. 